\title{
TOURISM GOVERNANCE IN KOMODO NATIONAL PARK, INDONESIA: BLESSING OR CURSE?
}

\author{
Abdul KODIR* \\ University Negeri Malang, Faculty of Social Science, Sociology Department, \\ Bd I1 Jalan Semarang No 5 Malang, Indonesia, e-mail: abdul.kodir.fs@um.ac.id

\section{Ardyanto TANJUNG} \\ University Negeri Malang, Faculty of Social Science, Geography Department, \\ Bd I1 Jalan Semarang No 5 Malang, Indonesia, e-mail: ardyanto.tanjung.fis@um.ac.id
}

\section{SUMARMI}

University Negeri Malang, Faculty of Social Science, Geography Department, Bd I1 Jalan Semarang No 5 Malang, Indonesia, e-mail: sumarmi.fis@um.ac.id

\section{Risdawati AHMAD}

University Negeri Malang, Faculty of Social Science, Sociology Department, Bd I1 Jalan Semarang No 5 Malang, Indonesia, e-mail: risdawatiahmad@gmail.com

\section{Theo Benardo SIMANJUNTAK}

University Negeri Malang, Faculty of Social Science, Geography Department, Bd I1 Jalan Semarang No 5 Malang, Indonesia, e-mail: theobernardo@gmail.com

\begin{abstract}
Citation: Kodir, A., Tanjung, A., Sumarmi, Ahmad, R., Simanjuntak, T.B. (2019 TOURISM GOVERNANCE IN KOMODO NATIONAL PARK, INDONESIA: BLESSING OR CURSE? GeoJournal of Tourism and Geosites, 27(4), 1663-1667. https://doi.org/10.30892/gtg.27424-443

Abstract: This study aims to explain the management of tourism in the Komodo National Park (KNP). Besides, this study portrays the impact of tourism management on the socio-economic life of people living nearby the KNP. This study employed qualitative research methods. The data were obtained from interviews with community leaders, naturalist guides, village heads, tourism managers, fishers, and tourism management communities in the region. Two villages in the KNP were chosen as the data collection sites. The results of this study indicate that the management of tourism in the Komodo National Park area is dominated by the KNP Officer, while the local people exclusively positioned as natularist guide. Besides, this study shows that the existence of tourism in the national park only impacts on people living in the Komodo island region which exclude people living in the island of Rinca from welfare and prosperity.
\end{abstract}

Key words: tourism, governance, national park, komodo, blessed, curse

\footnotetext{
* Corresponding author
} 


\section{INTRODUCTION}

Tourim sector is an alternative sector owned by each country to help increase Gross Domestic Product (GDP) (Eugenio-Martin et al., 2008), reduce poverty (Vanegas et al., 2015; Ramukumba, 2019) and have the potential to develop peripheral communities (Keyim, 2017). However, at the same time, tourism also impacts on environmental damage (Daby, 2003; Kurniawan et al., 2016), land grabbing (Zoomers, 2010), land acquisition (Kodir, 2018), water crisis (Cole, 2012) and often causes social conflict (Lee et al., 2010). In the context of Indonesia, the tourism sector is one of the alternative sectors to increase foreign income, increase investment, and develop the region. Each region is encouraged to develop tourism potential.

One of them is to establish policies through Government Regulation Number 50 of 2011 concerning the National Tourism Development Master Plan 2010-2025 (Bappenas, 2016). The follow up of the regulation is to establish ten priority tourism destinations with the protection of the Tourism Authority Agency (BOP). One of the areas determined is Komodo National Park (KNP). The determination of the Komodo National Park region as one of the priority tourism destinations in Indonesia because this region is one of the seven wonder of the world. This area was designated as the Komodo National Park on March 6, 1980 and was declared a Human and Biosphere Reserve in 1977 as a World Heritage Site by UNESCO in 1991, as a National Symbol by the President of the Republic of Indonesia in 1992, as a Marine Protected Area in 2000 and also as one of the Model National Parks in Indonesia in 2006. Not only that, Komodo National Park waters ranked second as Wolrd Best Snorkeling in 2015 (CNN Survey).

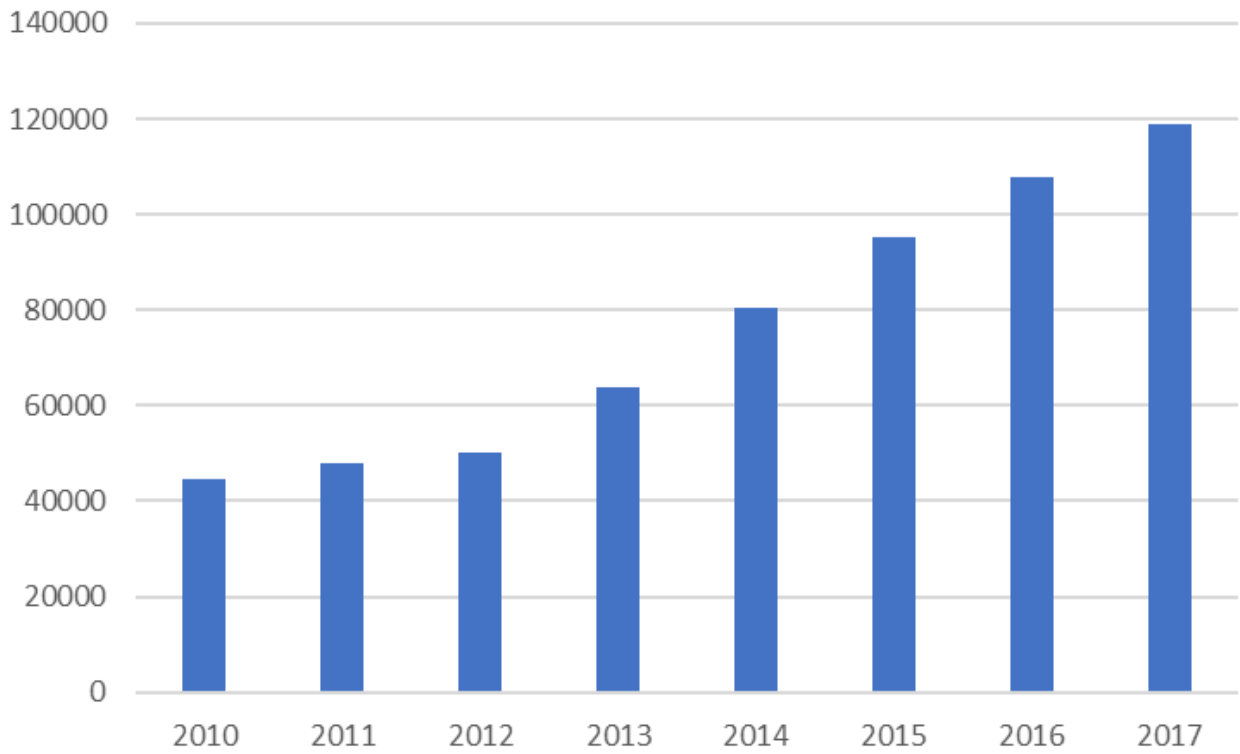

Figure 1. The number of tourists visiting the Komodo National Park from 2010 to 2017 (Source: https://travel.tempo.co, 2017)

From figure 1, it can be seen that the number of tourists visiting Komodo National Park constantly increases every year. Even in 2018 (January - August), the number of tourists reached 126.599 people (https://travel.kompas.com, 2018). However, whether the management of tourism has an impact on improving life of the 
people living in the KNP area is not very visible. Even so far, the management of tourism in the KNP region reaps the pros and cons on the part of the community.

As an example, one controversy aligned when the tourism management was surrendered to the private sector happened from 2003 to 2012, led by PT. Putri Naga Komodo (a private company managing the Komodo National Park).

After several years of operation, the company went bankrupt, and there was no clear public accountability. At this time, the community did not reap the benefits of this management. Given the aforementioned discussions above, this study aims to explain the dynamics of tourism management in the Komodo National Park area. This present study encompasses (1) who the actors that dominating in the tourism management and how this tourism is managed, and (2) the extent to which tourism management has an impact on socio-economic-political life of people living in the Komodo National Park, especially on Komodo Island and Rinca Island.

\section{LITERATURE REVIEW}

Tourism plays a strategic role and has served as one of the pivotal pillars in the framework of national economic development. As one of the industrial sectors, tourism can be utilized to increase state revenue apart from other commodities. At present, the development of the tourism sector also contributes to the country's foreign exchange earnings. In Indonesia, for instance, the tourism sector ranks in the $4^{\text {th }}$ position after oil and gas, coal, and palm oil in terms of national foreign exchange earnings. Thus, the Indonesian government projects that by 2020 it can accelerate to be a major source of foreign exchange exceeding three other commodities in the country.

The projection of the tourism sector revenue is extremely optimistic inasmuch Indonesia is a country that holds a million natural beauty. One of them is the Komodo National Park. As one of Indonesia's tourism centers, this region is a central attraction for researchers to conduct tourism studies in the region.

One of the factors that encourage tourists to visit the Komodo National Park is due to the natural factors. A recent study conducted by Atahena et al. (2015) explained that most of the attractions for tourists to visit the National Park were natural factors and tour package prices (34.9\%) and transportation and hotel factors (17.8\%). Meanwhile, the existence of tourism in the Komodo National Park region directly or indirectly impacts on the local economy of the people living in the Komodo National Park area (Walpole \& Goodwin, 2000; Jaddah et al., 2015). The impact is mainly on shifts in livelihoods, aside from benefits of fishing sector. Many of the poeple are involved in souvenir tradings and work as tourism guides (Jaddah et al., 2015).

Besiedes, human activities (tourism) in the Komodo National Park area have an impact on the pattern of distribution and activities of the Komodo dragon (Ardianto, et al., 2018). Albeit extensive studies have been enacted to uncover the socio-economic benefits of the Komodo National Park to the people in the region, little attention has been addressed to explore the extent of the impact of tourism on local communities within the Komodo National Park. It is for this reason that the present study is carried out. It attempts to unveil whether the tourim in the Komodo National Park entails positive impacts on the people's social life and the natural environment.

This study generates an issue raised by Cochrane (2013), contending that the Komodo Co-Management Initiative failed to design and implement tourism management policies, especially in involving tourists. This is because the management of tourism policies in the national park areas is different from those outside the national park. Tourism management in the national park areas remain very complex inasmuch 
they have to maintain conservation activities (Eagles, 2010; Kalternbon et al., 2011; Puhakka \& Sarinen, 2013; Kruger et al., 2017; Fredman \& Wikstrom, 2017).

\section{METHOD AND RESEARCH AREA}

To obtain answers of the research formulation, this study employed qualitative method . The study was conducted from 2 June to 29 July 2019. The data were collected through two stages. First, conducting interviews with several related stakeholders such as Komodo National Park Officer, community leaders, village heads, hamlet heads, village officials, traditional communities, naturalist guides, Kompas Community, Kogetta Community, fishing communities, and entrepreneurs in the field of tourism.

Second, initiating a focus group discussion with the local community. In addition, observations were also geared to capture tourism activities in the region. The data collection process was carried out in Komodo and Rinca Islands. These islands have become tourist destinations due to the existence of Komodo dragons.

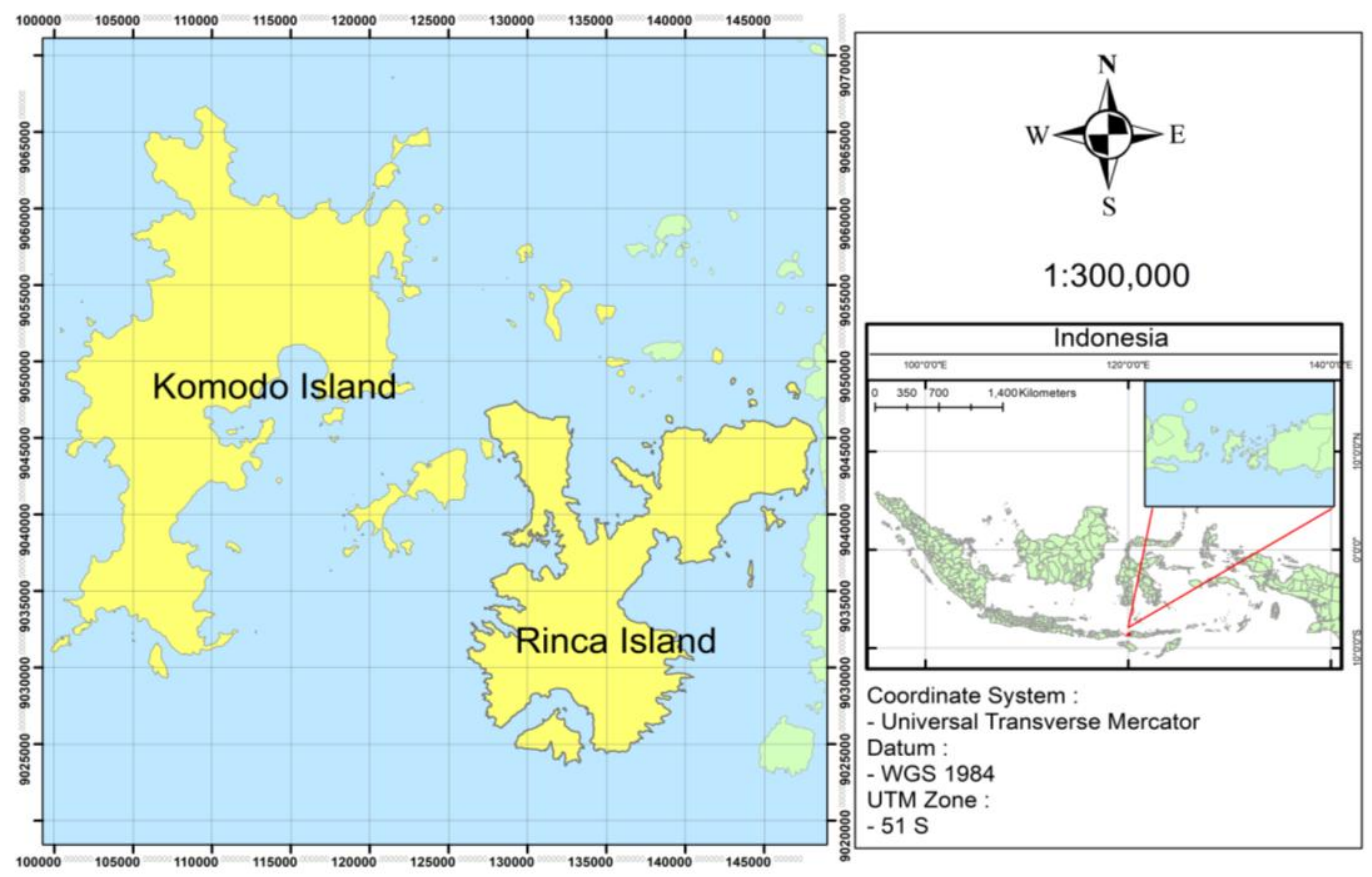

Figure 2. Geographical Location of the Research Area

The analysis of this study was carried out within several processes in the qualitative approach such as (1) data reduction which covers the process of selecting, focusing, abstracting, and transformating data, (2) presentation including a description of the conclusions of arranged information that makes it possible to draw the conclusions, and (3) conclusion and verification.

\section{RESULT AND DISCUSSION}

\section{History of the Determination of the Komodo National Park}

The national park is a nature conservation area containing native ecosystems. It is managed with a zoning system and is utilized for research, science, education, 
supporting cultivation, tourism, and recreation. Based on its management objectives, the use of interest is focused on science and tourism for the interests of parties from outside the region (Kosmaryandi, 2012). However, it is not easy to accommodate all the interests of various actors in management in protected areas (Rotich, 2012).

Komodo National Park is one of the national parks in Indonesia located between the Province of West Nusa Tenggara (Sumbawa Island) and the Province of East Nusa Tenggara (Flores Island). The main attraction of this national park is the existence of Komodo dragons. Komodo is one species of animal whose existence is protected since the days of Dutch colonial rule until now. According to Minister of Forestry Decree No. 306/Kpts-II/1995, this animal was discovered by JKH Van Steyn in 1911 and was named Varanus Komodoensis by PA. Ownes in 1912. In order to protect these endangered animals, various attempts were made by local and international governments, one of them by giving names to the areas where these animals are based on their functions and purposes. This naming has been done several times starting from "Animal Sanctuary" to "National Park" as it is today. The following table describes the evolution of the Komodo National Park name from 1926 to 1992.

Table 1. Evolution of the Name of the Komodo National Park

\begin{tabular}{|c|l|l|}
\hline Year & \multicolumn{1}{|c|}{ Naming } & \multicolumn{1}{|c|}{ Legal } \\
\hline 1926 & Animal Sanctuary & $\begin{array}{l}\text { Besluit van het Zelfbestuur van het Landschap Manggarai, } \\
\text { followed the previous regulation on the protection of } \\
\text { Komodo dragons in 1926 Rinca Island and Padar Island } \\
\text { became part of the Wildlife Sanctuary in 1939 because } \\
\text { Komodo dragons were also in this island (found on } \\
\text { Zelfbestuur van Manggarai verordening No.32 / 24 } \\
\text { September 1938 and Resident van Timor en onder } \\
\text { horigheden No.19 27 January 27 1939). }\end{array}$ \\
\hline 1965 & Wildlife reserve & $\begin{array}{l}\text { Decree of the Minister of Forestry No.66 / Dep.Keh / 1965 } \\
\text { dated October 21, 1965, concerning the Appointment of } \\
\text { Komodo Island as a Wildlife Sanctuary. } \\
\text { Based on the Decree (SK) of the Governor of KDH Tk. I. } \\
\text { East Nusa Tenggara No.32 of 1969 on June 24, 1969, } \\
\text { Komodo Island, Rinca Island, and Padar Island were } \\
\text { designated as Forest Tourism in 1969. }\end{array}$ \\
\hline 1977 & $\begin{array}{l}\text { United Nations Educational, Scientific and Cultural } \\
\text { Organization (UNESCO) in 1977. }\end{array}$ \\
\hline 1980 & Keserve (Cagar Biosfer) & $\begin{array}{l}\text { Minister of Agriculture Announcement on March 6, 1980, } \\
\text { regarding the Establishment of the Komodo National Park. }\end{array}$ \\
\hline 1991 & World Heritage Site & UNESCO \\
\hline 1992 & National Komodo Park & $\begin{array}{l}\text { Minister of Forestry Decree No.306 / Kpts-II / 1992 dated } \\
\text { February 29, 1992 there was a change in the function of } \\
\text { Wildlife Reserves for Komodo Island, Rinca Island and } \\
\text { Padar Island (area 40,728 Ha) and the appointment of } \\
\text { surrounding sea waters (area 132,572 Ha) located in the } \\
\text { Regency Dati II Manggarai Dati II Province East Nusa } \\
\text { Tenggara became the Komodo National Park. }\end{array}$ \\
\hline
\end{tabular}

Based on the table above, the name alteration of the Komodo National Park has been carried out six times both by local, central, and international governments. Precisely in 1992 which was the culmination of the naming of Komodo National Park President Soeharto set the Komodo dragon as a symbol of national animals through Presidential 
Decree No.4 of 1992 on January 9, 1992. The determination of Komodo Island as a national park area is one of the global symptoms that occur not only in Indonesia. But also in developing countries that have rich biodiversity (Rotich, 2012).

The main purpose of establishing it as a National Park area is to protect the Komodo National Park area from damage, one of which is caused by fishing activities when fishing. In general, zoning is a common tool in protected areas, especially for managing tourist visits (Thede et al., 2013). However, the determination of this zone does not take into account the existence of humans who also live in it, where most of them work as fishermen who depend their lives on the sea. Empirically, the zoning determination narrows and limits the areas inhabited by indigenous peoples ( $\mathrm{Li}, 2001$ ).

Conservation, Tourism, and Change of Livelihoods of Local Communities in the Komodo National Park Area

The main goal of establishing Komodo Island and Rinca Islands as national parks is conservation efforts. These efforts sometimes trigger different effects at one time. First, conservation contributes greatly to causing poverty to indigenous peoples because of the expropriation of their land and resources. On the other hand, in other cases, conservation projects offer opportunities for indigenous peoples to advance their perspectives on traditional land management and the natural environment (Popova, 2014), one of which is the tourism development project. Both impacts are logical consequences when conservation becomes a market expansion of neoliberalism (Kelly, 2011; Ojeda, 2012; Holmes, 2015; Rea, 2015; Suarez, 2015). The designation of the two islands as conservation areas plays an important role in changes in the livelihoods of the people in the area. However, the people who feel the most impact from the existence of a national park are only the people on Komodo Island, especially in Komodo Village, as is the case with the community on Rinca Island in Pasir Panjang Village which does not significantly affect livelihood changes. Pasir Panjang (a long beach) is a village on Rinca Island with an area of $19.625 \mathrm{Km}^{2}$ which consists of two hamlets namely the Komodo Hamlet and Bajo Hamlet, as well as two villages located on another island, one village located on Kukusan Island and one other village on Kerora Island.

From the north, the village is bordered by Papagarang Island and from the south, it is bordered by Kode Island and Motang Island, while in the east it is bordered by the plains of Flores Island and Labuan Bajo, in the west bordering Padar Island. The first indigenous people who lived in the village of Pasir Panjang were people who came from Komodo Island (Komodo Tribe) and Bajo Tribe. In addition to these two tribes, now many migrants settled in Pasirpanjang, they came from Bima, Selayar, Flores, Ende, and Java. Increasing numbers of migrants have led to an increase in the number of residents in this village. In 2016 there were 1,612 residents (BPS, 2016).

The majority of the population in Pasir Panjang Village work as fishermen. They catch fish using nets and trawl. This expertise was obtained after the arrival of people from the Bajo Tribe. Previously, the people's livelihood here was gardening in the fields. However, at this time, besides catching fish, they also catch sea cucumbers or so-called meting. Meting has a high sale value, usually marketed to collectors in Labuan Bajo and then sent abroad, such as in Hong Kong. Meting that is sold is black and brown, while white is consumed by the community. Besides the meeting, another catch that has economic value is lure (a kind of dried anchovy). The lure is sold to collectors in the village, and some others are sold directly to Labuan Bajo. The way to catch lure is very simple, using traditional equipment, such as nets, fishing rods, tide pairs, and tuba pairs.

This activity is carried out by almost all people in the village of Pasir Panjang, especially men, but it is not uncommon to see small children also joining their parents at 
sea. The fishing activity is almost done every day with income that does not settle depending on natural conditions. The weather supports them to earn an income of Rp. 20.000.000- up to Rp. 30.000.000-, and then this income is shared between the shipowner and the crew, one ship usually has 3 to 5 crew members (Interviewed, 2019). However, if the natural conditions do not support the income that can be drastically reduced. Nevertheless, the people in this village have remained as fishermen to this day. For them, the sea is the source of life provided by God for them.

After the area has been designated as the Komodo National Park area, frequent turmoil between the local community and the government or the Komodo National Park Office (BTNK) based in Labuan Bajo raised exclusively. The disputes are mainly related to zoning arrangements affecting fishing activities since it has been widely known that the Komodo National Park has been under the management of the Komodo National Park Office (BTNK) since 1992. BTNK is a Technical Implementation Unit (UPT) under the direct supervision of the Directorate General of Conservation of Natural Resources and Ecosystems, the Ministry of Environment and Forestry. The main task of BTNK is to arrange to zone for nature conservation. And also as a key tool in strategies for sustainable tourism (Lane 1994). However, the government does not involve the community in the structuring process such as zoning points that cannot be trampled by humans except in the context of regional development. This rule causes people to lose fishing locations. In practice, the formal determination of national park zoning causes community access to natural resources to be limited (Kormaryandi et al., 2012).

A further impact felt by the community is to find fishing locations in places farther from their residences, with greater safety risks and higher expenses for fishing needs such as fuel, food, and other needs. In addition, they also often encountered unfavorable treatment from officers who conduct sea security, especially at zoning points when caught doing fishing activities. Even so, they remain as fishermen today. The difference, if around the year 2003 when PT. TNC is still involved in the management of the KNP area, and the movement of fishers is relatively limited by zoning. Afterwards, since 2010 after TNC decided to stop the TNK management permit, the policy began to fade, the level of sea security carried out by officers began to decrease, so that the community felt a little more free to catch fish in any location than before. Even so, the community claimed that there were still patrols that were sometimes carried out by officers, although not as strict as before. Aside from working as a fisherman, the people in the village of Pasir Panjang also have other jobs in the field of tourism. However, the number is scant. The types of livelihoods in the field of tourism include:

Table 2. Types of Livelihoods of Pasir Panjang

Communities in the Tourism Sector (Data source: Interview, 2019)

\begin{tabular}{|c|c|c|c|c|}
\hline $\begin{array}{c}\text { Types of } \\
\text { Livelihoods }\end{array}$ & $\begin{array}{c}\text { Naturalist } \\
\text { Guide }\end{array}$ & $\begin{array}{c}\text { Souvenir } \\
\text { Seller }\end{array}$ & $\begin{array}{c}\text { Homestay } \\
\text { Providers }\end{array}$ & $\begin{array}{c}\text { Sea transportation } \\
\text { service provider }\end{array}$ \\
\hline Numbers & 30 & 1 & 3 & 3 \\
\hline
\end{tabular}

If calculated from the whole community in this village, there is only $5 \%$ of the total population work in the tourism sector, while the rest still maintain their old occupation, such as fishing. Based on this fact, it is concluded that the national park has not had a significant influence on the changes in people's livelihoods in the village of Pasir Panjang on the island of Rinca. This is because the villagers who live on Rinca Island do not benefit from the existence of tourism. Such conditions are as described by Mutanga et al. (2015) that not all communities living in conservation and tourism areas benefit 
Abdul KODIR, Ardyanto TANJUNG, SUMARMI, Risdawati AHMAD, Theo Benardo SIMANJUNTAK

financially from the industry. This is different from the community life in Komodo Village, located on Komodo Island. This village consists of 4 hamlets with a population of 1.714 people in 2016. The population in this village continues to increase from year to year, but the availability of residential land is very limited, this is because the Komodo Village is included in a "special zone" that does not require human existence inside, for they want to preserve Komodo dragons. This separation process is a form of control related to what can and may not be done by humans (Adams, 2019).

As a result, the condition of settlements in this village seems crowded with a distance of only 3 meters between one house and another house, meaning that there is little or no land that residents can use as their yard. The effort was driven by the pretext of guarding the wild animals against extinction (Adams, 2016). Supposedly, in controlling these wild animals, it is not necessary then to drive the people out of their places of residence, but instead use technology such as radio, satellite tracking, cameras and audion to control their movements (Adams, 2019). The inhabitants of Komodo Village are not only native to Komodo but also migrants from other areas such as Sumba, Atalabo, Bima, Ambonese, Bajo and Bugis people. The migrants live and mingle with native Komodo dragons and influence the type of livelihood of the people in this village. In general, the people of Komodo Village have experienced three changes in livelihoods.

Table 3. Changes in Livelihoods of community in Komodo Island (Data source: Interview, 2019)

\begin{tabular}{|c|c|c|c|}
\hline Year & Before 1980 & $\mathbf{1 9 8 0}-\mathbf{1 9 9 6}$ & After 1996 \\
\hline Type of livelihoods & Hunting and gathering & Fisherman & Tourism services \\
\hline
\end{tabular}

Before 1980, the main livelihood of Komodo dragons was to utilize forest products by gathering and hunting and fishing using traditional methods such as nets. In general, they take branches from the forest, collect acids, and hunt deer. Gabang is a kind of wild tubers in the forest. At that time, community settlements were still scattered along the island. Some live in mountainous areas such as in Bukit Ara, and some live in coastal areas. The form of settlements is grouped according to the type of tribe. Their lives at that time mingled with Komodo dragons, although famous for being wild and wild, but the Komodo community did not feel threatened by its existence.

In addition to searching for forest products, they also hunt deer. During hunting, Komodo's people have a close relationship with Komodo dragons. Usually, the hunted animals are killed in the forest, then the head, legs, skin, and organs are left for the dragons, while the rest is taken home. For the Komodo community, this animal is not as extensive as one might imagine, but it can attack someone if it feels threatened.

In the same period, before 1980 , some people in this village, especially migrants from Sulawesi, made a living as fishermen. In 1980 (the second period), along with the formation of the Komodo National Park Area, people's lives began to change drastically. This island is designated as a protected zone which requires that all human activities in the area be removed. Along with the determination of this zoning, another policy emerged that the Komodo Village community was prohibited from doing activities in forest areas such as gathering and hunting deer activities as they did before because they were referred to as illegal poachers. There was even a plan to relocate Komodo settlements to the mainland of Flores Island, but in the end, it failed because of resistance from the local community. Even though the policy was considered arbitrary, the people could hardly resist, because, at that time, the Suharto regime was in power with a militaristic approach that tended to be intimidating and not infrequently violent. This practice confirms that 
conservation as a form of accumulation by dispossession (Benjaminsen \& Bryceson 2012). As a result of zoning, the form of community settlements has changed, from being initially dispersed to being forced to live in a limited location. Before the existence of KNP, community settlements could be found in Loh Liang, which is now the center of tourism on Komodo Island. The location which is used as a place for community relocation is on the coast of Komodo Village, which is made to extend along the coastline.

Initially, for the reasons of conservation the people who built houses here were monitored by the government, they could only use reeds as roofs, not allowed to use zinc roofs. Changes to the lives of Komodo dragons not only touch the form of the settlement but also affect people's livelihoods. At that time, the community began to turn into fishers and they learned how to sail from migrant tribes such as the Bugis and Bima tribes who had become fishermen first. Marine products in the Komodo National Park (TNK) are very abundant because geographically the TNK region is between the confluence of the Flores Sea and the Indian Ocean. Natural resources found in the sea area are coral reefs, various types of fish, and plankton. Because of this, it is not surprising that TNK has become one of the best diving spots in the world based on the results of a $2015 \mathrm{CNN}$ survey (https://cnnindonesia.com, 2017).

In the past, the boat used by fishermen to catch fish was called bagang, a unique shape that was driven by wind power and was equipped with two right and left wings . This type of ship is called unique because there are two boats put together, then in the middle, there is a kind of small hut that is used to store lunch or a place to cook rice while waiting for the catch. In this period everyone has a butterfly because all the residents here become fishermen. Changes in livelihoods again occurred in 1997; some people in the village began working as artisans of Komodo statues and souvenir sellers.

At first, they were small groups that were getting bigger and bigger. Along with that, the number of fishers has also declined dramatically. Changes in livelihoods in this village are closely related to conservation management carried out by the government. This is very clearly seen when TNC and PT. Putri Naga Komodo (PNK) has been involved in the management of KNP since 1995. The privatization of TNK management was carried out by PT Putri Naga Komodo in 2004-2011, where its shareholders were PT. TNC. Based on interviews with local communities, the drastic changes that occurred in Komodo Village were based on at least three reasons. First, TNC and PNK encourage local people to work in the tourism sector. In realizing this, TNC gave a proposal to conduct training in the making of Komodo dragons and the manufacture of various types of souvenirs.

The reason used is because the fishing season is uncertain, sometimes fishermen do not go to sea due to unfavorable natural conditions so that free time can be used to make statues and souvenirs. At that time, the government brought artisans from Bali to train the local community. However, the transformation of tourism does not guarantee that local people are satisfied with their income in this sector (Lasso \& Dahles, 2018).

The second reason is that there is a zoning system that helps accelerate changes in people's livelihoods. The establishment of zoning aims to realize an optimal KNP management system, which is stipulated in PP No.68/1998 and revised in 2011 in PP No.28/2011 (Mahmud et. al, 2015). As a result of zoning, the fishermen's movements are not as free as before, and fishing equipment is limited, they are not allowed to use nets as high as 20-30 meters, and are not allowed to do fishing activities in diving locations, such as at Pink Beach. Pink Beach is a beach which is approximately 1 hour from the village of Komodo and is a favorite place for fishers to catch fish. However, this place is used as one of the zone points because there are matta fish whose population is protected by KNP. This place is also one of the diving spots that is the destination of 
tourists, so fishing activities are feared to disturb or endanger tourists who are diving. The stipulation of this regulation is still carried out, although it is not accompanied by clear socialization to the public. The government, through a joint operation between TNC, BTNK, and the sea police often conduct security in the zoning area.

People often get abusive treatment such as beatings, torture, and some are even jailed if they are caught doing fishing activities in a designated zone area. The third reason, because the velocity of money in the business of making dragons and souvenir sales is much faster than catching fish. The sea products are abundant, but the distance from the market that is used as a place to sell fish is very long, namely in Labuan Bajo, which is about 5 hours away. As a result of the factors above, slowly many people are involved in a business in the tourism sector, namely as a maker of Komodo dragons and souvenir sellers. Most people have left their profession as fishermen, and now only around $5 \%$ of the total population still maintains these livelihoods.

\section{Islands}

Limited participation of local communities in tourism in the two

The main task of the Komodo National Park Office (BTNK), as well as national parks in other countries, is to arrange to zone for the sake of biodiversity sustainability (Mules, 2015; Maidment, 2016; Cotoi, 2017; Fredman \& Wikstorm, 2018). BTNK is also authorized to regulate all activities of local communities in the area, including tourism activities that are now being carried out by the community. As we know that before engaging in tourism, the local community worked as fishermen, but because of the zoning stipulation at various points, the community lost the catchment area of the fish. Not only in Indonesia but also the existence of a national park causes more complex problems for indigenous peoples and local communities (Perez \& Bukluran, 2018).

Tourism policies that are increasingly pressing to encourage these communities to require them to switch livelihoods ( $\mathrm{Su}$ et al., 2016a; 2016b; 2019). Along with these conditions, the government and the authorities possessed these conditions as opportunities in developing the tourism sector in the Komodo National Park (TNK). To support tourism activities, it is not enough for the government to rely solely on dragons as an attraction for tourists. But other supporting aspects are needed, one of which is humans who are in the region itself. This is then used as an opportunity for the government by involving the community in tourism activities to support the tourism industry in KNP. Specifically, in Komodo Village, the government through PT. TNC brought in senior artisans from various regions to train local people in making Komodo.

In order to develop tourism in the region, the government labeled the Komodo Village as a "Tourism Village," so that visitors are curious about the history of Komodo, which is not only an animal name but an ethnic name. If only Komodo dragons are relied upon to attract tourists, visitors are less likely to come back to this area. Therefore, the Tourism Village was formed as an effort to attract visitors to come back later. However, the labeling of the Tourism Village is only on the signboard for the entrance of this village and is not followed by the development of the settlement as a tourist village.

To support the Tourism Village label, the KNP manager provides a trading location for souvenir sellers and other businesses in Loh Liang, which is a core zone of the KNP region as well as a place where visitors can see Komodo dragons. According to residents, the government only provided 144 tables to sell, and this number was not considered proportional to the population in Komodo Village. Each table is given a serial number. Serial number 1 is in the entrance area of the selling hall, followed by a serial number table 2 and so on. Oftentimes, traders draw to determine what table they sell at. Traders here not only consist of the local community, but there are also 
cooperatives owned by BTNK that sell similar souvenirs, namely Komodo clothing and trinkets from marine animals. The place to sell between the local community and the cooperative is differentiated, so there is competition for consumers. This competition is not very influential if the tourists who come in large numbers are around 500-1000 people, but the local community will be unable to compete if the visitors who come are around 5-10 people. To reduce this gap, BTNK recruits a few native Komodo dragons to become naturalist guides whose task is to guide tourists to see Komodo in Loh Liang.

Not many residents are involved in this work, only 60 people. They were divided into two groups, and one group consisted of 30 people, the work schedule for each group was two weeks a month, if the first group was in charge of eating the other group was closed, and vice versa. This work is dominated by young people and requires certain qualifications that cannot be automatically fulfilled by residents.

These qualifications include mastering English, having the ability to communicate, the level of education that is prioritized graduating high school/ vocational majoring in tourism, as well as being physically fit. Although training has been given in advance, this requirement can only be met by a handful of people. Those who do not have the opportunity to work in this field, take another alternative, namely to become Komodo sculpture craftsmen or souvenir sellers. Nevertheless, BTNK claims that they have involved local residents in tourism activities in the KNP area and have provided employment opportunities for local communities. The amount of wages earned by the naturalist guide is 40.000 rupiahs in a one-time guide. The amount is the result that has been divided in half with the manager. Visitors who come must pay 80.00o rupiahs to the manager, and then the manager shares with a naturalist guide. Sometimes in one day, the naturalist guide guides visitors about 5-6 times. Those who are not involved in the tourism sector managed by KNP decided to look for work outside their territory, one of them being a tour guide. This profession is occupied by 25 village youths. His job is to guide tourists from one island to another, in contrast to naturalist guides who only guide in Loh Liang alone, the task of tour guides is more complex.

The islands that are usually visited are Padar Island, Pink Beach, Kelor Island, Komodo Island, Kalong Island, and other tourist destinations in the KNP area. The tour guide collaborates with an agent-based in the City of Labuan Bajo, the agent will contact them if there are tourists who need their services. This work is not under the KNP office but is purely their own business. One tour guide person can have one or even more agents, depending on their ability to find an agent.

Other jobs in the Komodo Village in the tourism sector are homestays. Providers of homestay in this region are still few, namely 13 people. The homestay owner claimed that the homestay's existence in his village was not very attractive to tourists. The reason is because of the existence of a cruise ship that provides bedroom facilities for tourists so that tourists are no longer interested in staying at residents' homestays. This is acknowledged by residents because of the lack of firmness from the government which frees the entry and exit of cruise ships in the village of Komodo so that the homestays that now stand are merely displays. The involvement of the local community in the field of tourism can also be seen from motorcycle taxi service providers. There are 19 people working in this field. However, the work is purely a community's effort, and they are not facilitated or compiled by BTNK to work in this field. They have agents in Labuan Bajo who provide information if tourists need their services. The tour packages provided are to Padar Island, Loh Liang, Kelor Island, Kalong Island, Pink Beach, and other tourist destinations both within the Komodo National Park area or beyond. The type of ship used is the open deck, which, when compared with the shape and facilities of the cruise ship, 
the status of this ship is below it. The income obtained were around 2.000.00o rupiahs to 4.000.000 rupiahs in one tour. The results will be shared between ship owners and crew, and one ship usually has 3 to 5 crew members. Based on the data above, from all tourism jobs in Komodo Village, only two jobs were facilitated by BTNK, namely souvenir merchants and naturalist guides in Loh Liang. The number of jobs is also limited, only a handful of lucky people who can feel it. While those who are less fortunate, choose to work as craftsmen and work outside their territory. There are even some people who do not get the location of selling in Loh Liang, must peddle their wares directly by visiting tourists' boats. Because of their actions, they had to get rough treatment from government officials, they were beaten and their merchandise is thrown away. Nevertheless, the government still stated that the presence of KNP gave benefits to the local community. But if explored deeper, the region with its abundant natural wealth should be able to prosper the people more than that, not only as workers in the informal sector.

In addition to working in the tourism sectors which exclude local people, the management of tourist destinations on Komodo Island also does not involve the community. The community here has not been given the opportunity to manage tourist destinations in the region, except for tours around the village managed by BUMDES. Visitors who want to enjoy this tour must pay 10.000 rupiahs per person. Sometimes the villager's display shows to tourists or guests who come, and these shows are usually displayed that is Urugele. Urugele is played by a group of elementary school children in the village, and they will be rewarded after performing. Meanwhile, the tariff policy for tourist ships that enter or dock at the pier has not been carried out by tourism managers in this village. However, the village has made plans related to tariff management for ships that enter the village of Komodo, and they make a kind of tool as a place to put anchors on the edge of the pier. So if there is a ship that enters the village must anchor the ship in the area, and the village will determine the amount of the tariff. Furthermore, the village government plans to determine a policy so that ships that take guests to Loh Liang stop at Komodo Village, then the guests will be escorted to use small vessels owned by the village community. This policy is just a plan but has not been realized.

Not much different from Komodo Village, the involvement of village communities on Rinca Island in the tourism sector is very low, which is below $5 \%$. As many as 30 people work as naturalist guides, one souvenir seller, three homestay providers, and three motorcycle taxi motorcycle service providers. The low level of community participation is recognized because the government does not open access to the community. The number of naturalist guides in Loh Buaya is limited to 30 people, divided into two groups, one group consisting of 15 people with the same duration of work as the naturalist guide in Desa Komodo, which is two weeks a month. The task of the naturalist guide is to guide both local and foreign tourists visiting Loh Buaya to see Komodo.

In addition to the naturalist, Crocodile Loh guide is also usually assigned to guide tourists around the village in the village of Pasir Panjang or to Goa Kalong (one of the tourist destinations in the village of Pasir Panjang) to see bat/bats. The wage obtained by the naturalist guide at Loh Buaya is 40.000 rupiahs, to guide five tourists in one track. Usually, they get a wage of 200.000 rupiahs - up to 400.000 rupiahs per day from several tracking times. The wages are the results that have been shared with the national parks, national parks get 40.000 rupiahs, and naturalist guides get 40,000 rupiahs. The amount of wages is the same as the wages obtained from guiding tourists around the village or to Goa Kalong. Wages earned can increase depending on the kindness of tourists who provide additional bonus directly. Other tourism service providers in this village are souvenir sellers. There is only one person who works in this field, namely Haji Ishaka. 
He peddled his wares right next to the pier door in the hope that tourists visiting him would come and buy what he was selling. But very rarely there are tourists who stop by and buy because the number of tourists visiting his village is very small. The government also pays little attention to their fate, because it does not provide trading facilities in Loh Buaya such as in Loh Liang. All forms of trading activities in Loh Buaya are managed by cooperatives owned by the Komodo National Park Office. This is what causes the lack of community involvement in tourism activities. In addition to naturalist guides and souvenir sellers, the people of Pasir Panjang Village also provide homestays for tourists and visiting guests. However, there are only three people who are interested in this business. They set prices starting from 150.000 rupiahs up to 300.000 rupiahs per room in one night. Facilities provided include a bedroom, bathroom, and dining.

Cruise ships are special vessels provided by agents in Labuan Bajo to take tourists or guests in the Komodo National Park area. Its size is bigger than other tourist ships. The facilities provided are also more complete such as bedrooms, meals, small speed boats that are used to take tourists to the mainland when the ship is anchored, so the price is much higher compared to other ships in the range of IDR 10.000,000., and above. The completeness, which is owned by this ship makes tourists no longer need residents' homestays to rest. Usually, tourists only get off the boat to enjoy a tour around the village, after finishing they return to the ship and spend the night in it. The next community involvement in tourism is the provider of motorboat rental services for tourists.

There are three providers of this service. Ships are used to load open deck type passengers, which can accommodate 10 to 15 people. There are several tour packages provided starting from Loh Buaya, Padar Island, Strawbery Island, Kelor Island, and other destinations desired by tourists. To get passengers, they must work together with a travel agent based in Labuan Bajo. The process of cooperation is that tourists contact the agent, then choose the package tour offered, as well as making payment transactions with the agent. However, according to the participants, they would benefit more from getting direct passengers without an intermediary agent. However, it is very rare for passengers to contact him directly, because the presence of agents in Labuan Bajo is more strategic, making it easier for tourists to reach.

The involvement of local people on Rinca Island in the tourism sector is very low compared to Komodo Island. TNK processors only provide opportunities for the community as naturalist guides even though the number is not proportional to the total population. In addition, the management of tourist destinations on the island of Rinca also does not fully involve the community. There are only three tourist destinations currently managed by the village, namely Batu Balok, Goa Kalong, and tours around the village. There are two other destinations that will be managed but not yet implemented, namely Strawberry Island and Kalong Island. The party managing this destination is the Tourism Lover Community (KOMPAS). KOMPAS also has a management structure like other organizations whose positions are under the Village Owned Enterprises (BUMDES).

Tourism Lover Community (KOMPAS) was established in 2018, while BUMDES was only established in early 2019. During the trip, the two organizations argued over who should have the right to become a tourist destination in their region. BTNK gave the authority to BUMDES, but at that time KOMPAS was established first so that the village government gave that authority to KOMPAS. Every day alternately members of KOMPAS stand guard at the pier, waiting for tourists who want to go to Batu Balok, Goa Kalong, or tour around the village. Ticket prices to Batu Balok and Goa Kalong are 80,000 rupiahs for five people, the income obtained is divided between naturalist guide and KOMPAS. Meanwhile, for every boat that docked at the village pier, a tariff of 10.000 rupiahs per 
Abdul KODIR, Ardyanto TANJUNG, SUMARMI,

person, as well as tourists traveling around the village are charged the same price. Income obtained by KOMPAS until this research was conducted has not been used for any activity, because there is no planning related to the work program of KOMPAS. Income obtained is managed by the treasurer of the organization and will be shared with the village government (BUMDES), but the distribution is still not done. Discussion of financial problems will be conducted every six months while BUMDES get income from the business of renting chairs for events inside and outside the village such as weddings, celebrations, and other events. The number of seats owned by BUMDES is 200, and for them, it is very little. Both KOMPAS and BUMDES have not yet thought about the issue of member wages, because there has been no careful planning related to the management of income received so far, so far they are still working voluntarily without being paid.

The problem currently being faced by KOMPAS is related to the legal status of tourist destinations being managed. KOMPAS once carried out the legality of the Kalong and Batu Balok Cave, but it still did not comply with the rules set by BTNK. So that the legality that has been completed is not considered valid, this is because BTNK's policy is to make BUMDES a tourist destination manager, but in reality, the destination is still managed by KOMPAS. BTNK, as the giver of legality, refuses to issue the legality, because it is considered not following applicable regulations. This obstacle to the legality process is recognized because the education level of KOMPAS members is still low. Furthermore, their lack of knowledge of tourism is one of the obstacles for them to participate more in the tourism sector (Sihombing et al., 2017). Even though the status is illegal, the two destinations are still managed by KOMPAS. However, according to several informants, the legality still needs to be done to avoid problems in the future. Meanwhile, for the other two destinations, Kalong Island and Strawberi Island, they are still in the planning stage for the management process, because KOMPAS and the village government are still trying to make these two destinations manageable by the village.

Based on the results of the previous presentation, it was concluded that community involvement in the Komodo Village and the Pasir Panjang Village in the field of tourism was very limited. Local people are only involved in several occupations. They have never been involved in decision-making and resource management efforts (Prabakharan et al., 2014) both informally and formally (Bello et al., 2018) since tourism is only centralized to the incorporated institutions (Yankholmes, 2018). On Komodo Island, BTNK only provides facilities for two jobs; souvenir merchants and naturalist guides, albeit the fact that these are very limited numbers. While other jobs related to tourism are purely the efforts of the community themselves, not facilitated by BTNK. Meanwhile, on Rinca Island, the community is only facilitated as a naturalist guide. The government holds full power over KNP and does not give the opportunity to the public to express their aspirations related to tourism activities in KNP as desired by the community.

The community is not involved in planning various tourism activities carried out. However, it is only as an executor that all the rules of the game have been determined by the government. Thus, the community is only as a complement to a series of tourism activities. It can be concluded that the management of tourism in KNP has not been fully carried out for the welfare of the people, only a handful of people employed in the tourism sector are not proportional to the large population on these islands. The management of tourism in the KNP region enriches large investors. BTNK does not consider building informal economic sector relationships like other formal sectors with large capital (Thomas, 2007). Those who have capital, are given the opportunity to make decisions, practice, and implement tourism development strategies in the National Park area (Xue and Kerstetter, 2018). In addition, tourism management in the 
KNP area also does not involve local communities. Instead, those who sit in the government assigned to manage the KNP are those who come from outside the area. Local people should be involved because they know what is best for the lives of the whole community in the area. Not only that, if the community is truly involved in tourism management participation, it will have an impact on increasing household income (Owour et al., 2017; Keyim, 2018) and uplifting of standart of living (Strydom et al., 2019).

\section{CONCLUSION}

Based on this study, tourism management in the Komodo national park does not bring significant blessings and benefits to the local communities living in the Komodo and Rinca Islands. There is a shift in livelihoods for people on Komodo Island in term of the tourism sector which does not correspond to people livng on Rinca Island. The societies in Rica Island survive as fishermen inasmuch there is no access to tourism jobs, while the Komodo Island community has experienced five livelihood changes. Currently, the Komodo Island community engage actively in the field of tourism. Various types of jobs are found at the region, such as souvenir sellers, naturalist guides, tour guides, sellers at stalls/stalls, Komodo dragon artisans, tourist boats, and so on. Although there are more types of tourism jobs on Komodo Island, the Komodo National Park Office only provides jobs to be naturalist guides, while other jobs are purely community-owned businesses without the auspices of the Komodo National Park Office.

In addition, this study shows that the involvement of local communities in Rinca and Komodo Islands in the management of Komodo National Park tourism is relatively low. They only serve as a complement to the development of tourism. Tourism becomes a sector that seems to have no other choice for the community to choose from. Various systems and regulations are determined unilaterally by the government, such as zoning. Both Rinca Island and Komodo Island communities were only given authority to manage tourism in their villages. Menawhile, these two islands possess well established destinations such as Loh Buaya on Rinca Island and Loh Liang on Komodo Island, which provide quite high economic income for the region and country.

The present study is constraint to explaining the extent of community involvement in the tourism sector in the Komodo National Park and how the impact of tourism on improving the welfare of the people on Komodo Island and Rinca Island. Thus, further investigations on the relationship between local communities and BTNK who have full authority in managing tourism in KNP are encouraged.

\section{Acknowledgement}

This work was supported by PNBP research grant of Universitas Negeri Malang under contract No: 20.3.19/UN32.14.1/LT/2019

\section{REFERENCES}

Adams, M.W. (2017). Geographies of conservation I: De-extinction and precision conservation, Progress in Human Geography, vol. 41, no. 4, 534-545.

Ardiantono., Jessop, S.T., Purwandana, D., Ciofi, C., Imansyah, J.M., Panggur, R.M. \& Ariefandy, A. (2018) Efects of human activities on Komodo dragons in Komodo National Park. Biodiversity and Conservation.

Athena, A. \& Utama, G.R.I. (2018). Faktor-Faktor Yang Menentukan Wisatawan Berkunjung Ke Taman Nasional Komodo Di Kabupaten Manggarai Barat Nusa Tenggara Timur. 10(1), 54-61.

Bappenas., (2016). Pembangunan Pariwisata. Di dalam Multilateral Meeting I, 2016 Februari 29. Jakarta: Kedeputian Bidang Ekonomi-Bappenas.

Bello, G.F., Lovelock, B. \& Carr, N. (2018). Enhancing community participation in tourism planning associated with protected areas in developing countries: Lessons from Malawi, Tourism and Hospitality Research, vol. 18, no. 3, pp. 309-320 
Benjaminsen, A.T \& Bryceson, I. (2012). Conservation, green/blue grabbing and accumulation by dispossession in Tanzania, The Journal of Peasant Studies, vol. 39, no. 2, pp. 335-355.

Cochrane, J. (2013). Exit the Dragon? Collapse of Co-management at Komodo National Park, Indonesia, Tourism Recreation Research, vol. 38, no. 2, pp. 127-143.

Cole, S. (2012). A political ecology of water equity and tourism: A Case Study From Bali, Annals of Tourism Research, vol. 39, no. 2, pp. 1221-1241.

Cootoi, C. (2017). The Making of a National Park: Ruins of Nature and History in Northern Dobrudja, East European Politics and Societies and Cultures, vol. 31, no. 3, pp. 596-614.

Daby, D. (2003). Effects of seagrass removal for tourism purpose in Mauritian bay, Environmental Pollution, vol. 125, pp. 313-324.

Eagles, F.J.P. (2010). Trends in Park Tourism: Economics, Finance and Management, Journal of Sustainable Tourism, vol. 10, no. 2, pp. 132-153.

Eugenio-Martin, J., L., Martín-Morales, N. \& Sinclair, M., T. (2008). The Role of Economic Development in Tourism Demand, Tourism Economics, vol. 14, no. 4, pp. 673-90.

Fredman, P. \& Wikstrom, D. (2017). Income elasticity of demand for tourism at Fulufja"llet National Park, Tourism Economics, vol. 20, no. 10, pp. 1-13.

Holmes, G. (2015). Markets, nature, neoliberalism, and conservation through private protected areas in southern Chile, Environment and Planning A, vol. 47, pp. 850-866.

Kalterborn, P.B., Nyahongo, W.J. \& Kideghesho, R.J. (2011). The attitudes of tourists towards the environmental, social and managerial attributes of Serengeti National Park, Tanzania, Tropical Conservation Science, vol. 4, mo. 2, pp. 132-148.

Kelly,B.A. (2011). Conservation practice as primitive accumulation, The Journal of Peasant Studies, vol. 38, no. 4, pp. 683-701.

Keyim, P. (2017). Tourism Collaborative Governance and Rural Community Development in Finland: The Case of Vuonislahti, Journal of Travel research, pp. 1-12.

Kodir, A. (2018). Tourism And Development: Land Acquisition , Achievement Of Investment And Cultural Change (Case Study Tourism Industry Development In Batu City, Indonesia), GeoJournal of Tourism and Geosites, vol. 21, no. 1, pp. 253-265.

Kosmaryandi, N., Basuni, S., Prasetyo, B.L. \& Adiwibowo, S. (2012). Gagasan Baro Zonasi Taman Nasional: Sintesis Kepentingan Konservasi Keanekaragaman Hayati dan Kehidupan Masyarakat Adat, JMTH, vol. 18, no. 2, pp. 69-77.

Kruger, M., Merwe, V.D.P., Saayman, M. \& Slabbert, E. (2017). Understandin accommodation preferences of visitors to the Kruger National Park, Tourism and Hospitality Research, vol. o, no. o, pp. 1-16.

Lane, B. (1994). Sustainable rural tourism strategies, Journal of Sustainable Tourism, vol. 2, no. 1-2, pp. 102-112.

Lasso, A. \& Dahles, H. (2018). Are tourism livelihoods sustainable? Tourism development and economic transformation on Komodo Island, Indonesia, Asia Pacific Journal of Tourism Research, vol. 23, no. 5, pp. 473-485.

Lee, T. J., Rilley, M. \& Hampton, M.P. (2010). Conflict and progress. Tourism development in Korea, Annals of Tourism Research, vol. 37, no. 2, pp. 355-376.

Li, M.T. (2001). Masyarakat Adat, Difference, and the Limits of Recognition in Indonesia Forest Zone, Modern Asian Studies, vol. 35, no. 3, pp. 645-676.

Maidment, C. (2016). In the public interest? Planning in the Peak District National Park, Planning Theory, vol. 15 , no. 4 , pp. $366-385$.

Mahmud, A., Satria, A. \& Kinseng, R. (2015). Zonasi Konservasi untuk Siapa? Pengaturan Perairan Laut Taman Nasional Bali Barat, Jurnal Ilmu Sosial dan Ilmu Politik, vol. 18, no. 3, pp. 237-251.

Mules, T. (2005). Economic impacts of national park tourism on gateway communities: the case of Kosciuszko National Park, Tourism Economics, vol. 11, no. 2, pp. 247-259.

Mutanga, N.C., Vengesayi, S., Gandiwa, E. \& Muboko, N. (2015). Community perceptions of wildlife conservation and tourism: A case study of communities adjacent to four protected areas in Zimbabwe, Tropical Conservation Science, vol. 8, no. 2, pp. 564-582.

Muthiah, J., Soekmadi, R. \& Nurrochmat, R.D. (2015). Dampak Kegiatan Wisata Alam Bagi Masyarakat Dalam Kawasan Taman Nasional Komodo Provinsi Nusa Tenggara Timur, Risalah Kebijakan Pertanian dan Lingkungan, vol. 2, no. 1, pp. 60-69.

Ojeda, D. (2012). Green pretexts: Ecotourism, neoliberal conservation and land grabbing in Tayrona National Natural Park, Colombia, The Journal of Peasant Studies, vol. 39, no. 2, pp. 357-375.

Owuor, G., Knerr, B., Ochieng, J. \& Wambua. T. (2017). Community tourism and its role among agropastoralists in Laikipia County, Kenya, Tourism Economics, vol. 23, no. 1, pp. 229-236. 
Perez, L.P. \& Bukluran. (2018). Living with the problem of national parks: Indigenous critique of Philippine environmental policy, Thesis Eleven, vol. 145, no. 1, pp. 58-76.

Popova, U. (2014). Conservation, Traditional Knowledge, and Indigenous Peoples, American Behavioral Scientist, vol. 58, no. 1, pp. 197-214.

Prabhakaran, S., Nair, V. \& Ramachandran, S. (2014). Community participation in rural tourism: Towards a conceptual framework, Procedia - Social and Behavioral Sciences, 144, pp. 290 - 295.

Puhakka, R. \& Saarinen, J. (2013). New Role of Tourism in National Park Planning in Finland, Journal of Environment \& Development, vol. 22, no. 4, pp. 411-434.

Ramukumba, T. (2019). Community Views on The Role of Tourism in Local Development: A South African Study, GeoJournal of Tourism and Geosites, vol. 25, no. 2, pp. 638-647.

Rea, M.C. (2015). Commodifying conservation, Contexts, vol. 14, no. 1, pp. 72-73.

Rotich, D. (2012). Concept of Zoning Management in Protected Areas, Journal of Environtment and Earth Science, vol. 2, no. 10, pp.173-183.

Sihombing, A., Gunawijaya, J. \& Akbar, G.N.P. (2017). Local Tourism Awareness and Knowledge: Community Views in Wanayasa, e-Review of Tourism Research (eRTR), vol. 14, no. 5/6, pp. 188 - 123.

Strydom, A.J., Mangope, D. \& Henema, U.S. (2019). Making Community-Based Tourism Sustainable: Evidence From The Free State Province, South Africa, GeoJournal of Tourism and Geosites, vol. 24., no. 1, pp. 7-18.

Su, M.M., Wall, G. \& Xu, K. (2016a). Tourism-Induced Livelihood Changes at Mount Sanqingshan World Heritage Site, China, Environmental Management, vol. 57, no. 5, pp. 1024-1040.

Su, M.M., Wall, G. \& Jin, M. (2016b). Island livelihoods: Tourism and fishing at Long Islands, Shandong Province, China, Ocean \& Coastal Management, vol. 122, pp. 20-29.

Su, M.M., Wall, G., Wang, Y. \& Jin, M. (2019). Livelihood sustainability in a rural tourism destination - Hetu Town, Anhui Province, China, Tourism Management, vol. 71, pp. 272-281.

Suarez, C.D. (2015). Transforming the frontier: peace parks and the politics of neoliberal conservation in southern Africa, The Journal of Peasant Studies, vol, 42, no, 2, pp. 452-456.

Thede, K.A., Haider, W. \& Rutherhord, B.M. (2014). Zoning in National Park: Are Canadian Zoning Practices Outdate?, Journal of Sustainable Tourism, vol. 22, no. 4, pp. 626-645.

Thomas, R. (2007). Tourism partnerships and small firms: Power, participation and partition, Entrepreneurship and Innovation, vol. 8, no. 1, pp 37-43.

Vanegas, M., Gartner, W. \& Senauer, B. (2015). Tourism and Poverty Reduction: An Economic Sector Analysis or Costa Rica and Nicaragua, Tourism Economics, vol. 21, no. 1, pp. 159-82.

Walpole, J.M. \& Goodwin, J.H. (2000). Local Economic Impacts Of Dragon Tourism In Indonesia, Annals of Tourism Research, vol. 27, no. 3, pp. 559-576.

Xue, L. \& Kerstetter, D. (2018). Discourse and Power Relations in Community Tourism, Journal of Travel Research, 2018, vol. 57, no. 6, pp. 757-768

Yankholmes, A. (2018). Tourism as an exercise in three-dimensional power: Evidence from Ghana. Tourism Management Perspectives, vol. 25, pp. 1-12.

Zoomers, A. (2010). Globalisation and the Foreignisation of Space: Seven Processes Driving the Current Global Land Grab, The Journal of Peasant Studies, vol. 37, no. 2, pp. 429-47.

*** Geographies of conservation II: Technology, surveillance and conservation by algorithm, (2019), Progress in Human Geography, vol. 43, no. 2, pp. 337-350.

*** Geographies of conservation III: Nature's spaces, (2019), Progress in Human Geography, pp. 1-13.

*** BPS Kabupaten Manggarai Barat. (2016). Manggarai Barat Dalam Angka 2016. Manggarai Barat: BPS Kabupaten Manggarai Barat.

https://www.cnnindonesia.com/gaya-hidup/20170720142305-307-229176/4-spot-diving-indonesia-masukjajaran-terbaik-di-asia, accesed 17.06.2019

https://travel.kompas.com/read/2017/11/15/120949927/komodo-disebut-alami-stress-berapa-banyak-turisyang-datang, accessed 13.06.2019

https://travel.tempo.co/read/1128459/kunjungan-wisatawan-ke-taman-nasional-komodo-melonjak-42persen/full\&view=ok, accessed 14.06.2019

Submitted:

26.06.2019
Revised:

18.12.2019
Accepted and published online 20.12.2019 